\title{
Effect of enzymatically hydrolyzed yeast on health and performance of transition dairy cattle
}

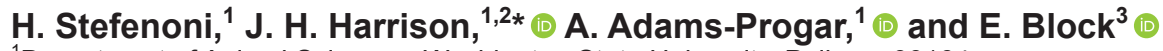 \\ ${ }^{1}$ Department of Animal Sciences, Washington State University, Pullman 99164 \\ ${ }^{2}$ Department of Animal Sciences, Washington State University, Puyallup 98731 \\ ${ }^{3}$ Church and Dwight Animal Nutrition, Princeton, NJ 08543
}

\section{ABSTRACT}

The objective of this study was to evaluate the effect of supplementing enzymatically hydrolyzed yeast (EHY; Celmanax Arm and Hammer Animal Nutrition, Princeton, NJ) on transition dairy cattle. Forty multiparous Holstein cows were blocked by predicted transmitting ability and randomly assigned to 1 of 2 treatments (EHY, $\mathrm{n}=20$; or control, $\mathrm{CON}, \mathrm{n}=20$ ) from $21 \mathrm{~d}$ before expected calving to $60 \mathrm{~d}$ postpartum. The EHY cows received 56 and $28 \mathrm{~g} / \mathrm{d}$ in close-up and lactating diets, respectively. Dry matter intake, health events, milk production parameters, feed efficiency, colostrum quality, reproductive parameters, body weight, and body condition score were monitored. Fecal samples collected on $-21,-14,-7,0,1,3,5,7$, and 14 d relative to calving were analyzed for total coliforms, Clostridium perfringens, Salmonella, and Escherichia coli O157:H7. Blood samples were collected at 7, 14, and $21 \mathrm{~d}$ postpartum for analysis of $\beta$-hydroxybutyrate. Sterile quarter milk samples collected at dry-off, calving, and wk 1, 2, and 3 of lactation were analyzed for milk pathogens and somatic cell count. Pre- or postpartum dry matter intake, body weight, body condition score, milk yield, and milk protein and fat yields did not differ among treatments. Milk fat and protein concentrations were greater in EHY cows than CON cows. $\beta$-Hydroxybutyrate and health events were not different among treatments. The presence of fecal $C$. perfringens did not differ prepartum, but was lower in EHY cows postpartum. Milk pathogens and total intramammary infections did not differ between treatments at dry-off, calving, wk 1, or wk 2, but more EHY cows were infected with Staphylococcus sp. during wk 3 than CON cows. The EHY cows showed heat earlier than CON cows, but no other reproductive parameters were affected. The EHY supplementation during the

Received July 29, 2019.

Accepted October 27, 2019.

*Corresponding author: jhharrison@wsu.edu transition period did not affect dry matter intake, milk yield, health events, or reproductive parameters but did increase milk protein and fat concentrations.

Key words: yeast, milk production, health

\section{INTRODUCTION}

The transition period, which is defined as 3 wk prepartum to 3 wk postpartum (Grummer, 1995; Grummer et al., 1995), is one of the most challenging stages during the lactation cycle. During this time, cattle become more susceptible to metabolic and infectious diseases, referred to as transition diseases or disorders. The innate and acquired host defenses in cattle during the transition period are challenged, increasing the susceptibility to disease (Goff, 2006). Around the time of calving, cattle increase the number of coliform bacteria shed in feces and this can increase the incidence of coliform mastitis (Pelan-Mattocks et al., 2000). By reducing pathogen loads in transition cattle, there is potential to decrease infectious diseases such as mastitis and metritis.

Saccharomyces cerevisiae is one of the most commonly used yeasts in ruminant nutrition (Chiquette, 1995). Certain strains and components of yeast cells have been shown to have an immuno-stimulatory effect by supporting rumen health and limiting the colonization and removal of pathogenic organisms (ChaucheyrasDurand and Durand, 2010; Nocek et al., 2011). Mannan oligosaccharides (MOS) are considered to be the main antigenic portion of yeast cells competing with gram-negative bacteria by binding to mannose-specific fimbria within the small intestine (Heinrichs et al., 2003). Beta-glucans can modulate or help regulate the inflammatory cytokines (Hoffman et al., 1993).

Yuan et al. (2015a,b) found that varying doses of Celmanax did not have an effect on BCS, milk production, or feeding behavior, but percentages of milk fat and milk protein tended to increase for cows fed 30 and $60 \mathrm{~g} / \mathrm{d}$, and linear SCS significantly decreased. A study conducted by Nocek et al. (2011) compared the 
production of early lactation cows fed yeast culture, enzymatically hydrolyzed yeast (Celmanax), and cows not fed a yeast-derived product. Cows receiving either yeast culture or Celmanax had increased ECM, and yields of protein, and fat throughout the first $11 \mathrm{wk}$ of lactation. Cows fed Celmanax had an increase in protein concentration compared with control and cows fed yeast culture. Milk urea nitrogen, BW, and BCS were not affected by treatment Additionally, no treatment effect was detected for the incidence of retained placenta, metritis, ketosis, or DA.

The effect of Celmanax on fecal pathogen shedding, milk pathogen shedding, milk production, milk components, colostrum IgG concentration, blood BHB, DMI, $\mathrm{BW}$, and BCS when fed to transition cattle (with different dosages pre- and postpartum) has not been evaluated. We hypothesized that cows receiving Celmanax would have less pathogen shedding with improved milk production, metabolic, and reproductive performance.

\section{MATERIALS AND METHODS}

\section{Animal Use}

Animal use and handling protocols were approved by the Washington State University Care and Use Committee (protocol 5009). This study was conducted at the Washington State University Knott Dairy Center in Pullman, Washington, between July 2017 and May 2018. Forty multiparous Holstein cows were randomly assigned to Celmanax (EHY; Arm and Hammer Animal Nutrition, Princeton, NJ; $\mathrm{n}=20)$ or control $(\mathbf{C O N}$; $\mathrm{n}=20$ ) groups and balanced for PTA (PTA for milk) values, parity, and expected calving date. All cows were housed in a freestall barn with compost bedding. Each cow was enrolled in the study upon time of dry-off and remained on the study until 60 DIM. Cows did not receive immunization with the Escherichia coli J5 vaccine at time of dry-off, 3 to 4 wk prepartum, or $3 \mathrm{wk}$ postpartum. They also did not receive immunization of 8 species or subtype of Clostridia vaccine (UltraChoice 8, Zoetis, Kalamazoo, MI) at 3 to 4 wk prepartum. All cows were moved to the close-up experiment pen $4 \mathrm{wk}$ before their expected calving date. Seven days before the expected calving date, cows were moved to a maternity pen to calve and returned to the experimental pen $3 \mathrm{~d}$ postpartum unless they required extra time due to a disorder or treatment with antibiotics. Milk yield was recorded twice daily.

\section{Feeding}

The diets were formulated for close-up or early lactation based on NRC requirements and fed ad libitum.
Table 1. Close-up TMR for control (CON) and Celmanax (EHY) treatments

\begin{tabular}{|c|c|c|}
\hline Item, $\%$ of DM & $\mathrm{CON}$ & EHY \\
\hline Corn silage & 37.25 & 37.25 \\
\hline Grain $\operatorname{mix}^{1}$ & 32.27 & 32.27 \\
\hline Grass hay & 20.32 & 20.32 \\
\hline Alfalfa hay & 10.16 & 10.16 \\
\hline \multicolumn{3}{|l|}{ Grain mix ${ }^{1}$} \\
\hline Soybean meal, $38 \%$ CP & 42.08 & 42.08 \\
\hline SoyChlor ${ }^{2}$ & 26.23 & 26.23 \\
\hline Ground barley & 22.14 & 20.88 \\
\hline Calcium carbonate & 4.20 & 4.20 \\
\hline Magnesium sulfate & 1.78 & 1.78 \\
\hline Choline (Reashure) ${ }^{3}$ & 1.36 & 1.36 \\
\hline Celmanax $^{4}$ & 0.00 & 1.26 \\
\hline Dicalcium phosphate & 1.15 & 1.15 \\
\hline Vitamin/trace mineral mix $^{5}$ & 0.94 & 0.94 \\
\hline Vitamin A & 0.06 & 0.06 \\
\hline Vitamin E & 0.04 & 0.04 \\
\hline Vitamin $\mathrm{D}_{3}$ & 0.02 & 0.02 \\
\hline
\end{tabular}

${ }^{2}$ Dairy Nutrition Plus (Ames, IA).

${ }^{3}$ Balchem (New Hampton, NY).

${ }^{4}$ Arm and Hammer Animal Nutrition (Princeton, NJ).

${ }^{5}$ Consisted of (\% DM): rice hulls, 29.39; limestone, 29.39; ManPro 80 (Zinpro Corporation, Eden Prairie, MN), 11.76; ZinPro 120 (Zinpro Corporation), 5.88; Zin 4-Plex C (Zinpro Corporation), 4.70; vitamin E $50 \%, 2.94 ; \mathrm{ZnSO}_{4}, 2.94 ; \mathrm{Mn} \mathrm{SO}_{4}, 2.94$; Sel-Plex (Zinpro Corporation), 2.35; CuPLEX 100 (Zinpro Corporation), 2.35; vitamin $\mathrm{D}_{3}, 2.35$; mineral oil, 1.76; $\mathrm{CuSO}_{4}, 0.59$; vitamin A, 0.35; selenium 1\%, 0.29 .

Cows were fed individually a TMR once per day using Calan doors (American Calan, Northwood, NH) throughout the duration of the experiment and were fed 5 to $10 \%$ in excess from the previous day's intake. Refusals were collected and weighed daily to determine DMI and cows had ad libitum access to water. Cows were fed either EHY close-up ration or CON close-up ration (Table 1) with EHY cows receiving $56 \mathrm{~g} /$ head per day of enzymatically hydrolyzed yeast. When cows freshened, they were fed either a EHY lactating ration or a CON lactating ration (Table 2). During the lactation portion of the study, EHY cows received $28 \mathrm{~g} /$ head per day of Celmanax.

\section{Feed Sampling}

Samples of TMR were collected once a week by randomly collecting approximately $500 \mathrm{~g}$ of each TMR from the Calan Super Data Ranger (American Calan) and frozen until time of analysis. Dry matter was determined by drying at $60^{\circ} \mathrm{C}$ for 1 wk in a drying oven. Subsamples of each TMR were analyzed for CP, soluble protein, NDF protein, ADF, NDF (ash-free NDF), lignin, ethanol-soluble carbohydrate, starch, ether extracts, ash, calcium, phosphorus, potassium, sulfur, sodium, chloride, iron, manganese, zinc, copper, and sulfur using wet chemistry (Cumberland Valley Analytical Services, Hagerstown, MD). 


\section{Animal Measurements}

Milk fever was defined by the presence of one or more of the following symptoms: the inability to stand postcalving, muscle tremors, or cold ears. Displaced abomasum was defined as diagnosed by a veterinarian. Subclinical ketosis was defined as a concentration of BHB of 1.2 to $2.0 \mathrm{mmol} / \mathrm{L}$, clinical ketosis was considered as BHB concentration of $>2.0 \mathrm{mmol} / \mathrm{L}$. Retained placenta was defined as retention of the fetal membranes for more than $24 \mathrm{~h}$ after calving. Metritis was defined as abnormal discharge characterized by purulent to brown uterine fluid associated with increased body temperature $>39^{\circ} \mathrm{C}$. Endometritis was characterized by the presence of purulent uterine discharge at $>21$ DIM. Clinical mastitis was defined with the presence of clotted milk with SCC $>200,000$ and body temperature $>39^{\circ} \mathrm{C}$.

All cows were weighed when moved to the close-up pen, approximately $28 \mathrm{~d}$ before their expected calving date, and then once each week until calving through 60 DIM. Body condition scores were assessed at dry-off, close-up, calving, and wk 2, 4, 6, and 8 of lactation. All BCS assessments were performed by the same person to avoid subjective differences on a 1 to 5 scale using 0.25 increments (Edmonson et al., 1989).

All cows were dried off 45 to $60 \mathrm{~d}$ before expected calving date. At time of dry-off, 10-mL sterile milk samples were collected from each quarter before milking using isopropyl alcohol and woven gauze sponges. After milking, all cows received dry cow therapy in the form of Spectramast DC (Zoetis, Parsippany, NJ) and Orbeseal (Zoetis). Sterile samples were collected from each quarter at time of calving (colostrum) and wk 1 to 3 of lactation. Milk samples were analyzed for pathogens, total SCC, and standard plate count by Udder Health Systems (Bellingham, WA). Procedure details are available at https://www.udderhealth.com/ services.htm. The equation used to calculate the log linear score of SCC was [ln (SCC)/0.6931] - 3.6439. The \% IgG in colostrum was measured with a Brix refractometer.

The pathogens reported from Udder Health Systems Inc. were used to determine new IMI. The pathogens from samples at dry-off were considered a baseline and pathogens in colostrum were compared with dry-off samples to determine new IMI. All new IMI were evaluated on a quarter basis. New pathogens present in a quarter were considered a new IMI. If the same pathogen was present in the following sampling, it was not considered a new IMI. If a pathogen was present at one sampling and then not observed in the 2 subsequent sampling times, but then again 3 sampling times later, it was considered a new IMI. Intramammary infec- tions on a cow basis were considered when one or more pathogens were present in one or more quarters at any given sampling time. Any samples with greater than 2 dissimilar colonies were considered contaminated and not considered as an IMI.

Fecal samples were obtained from the rectum using manual retrieval. During the close-up period, samples were collected 21, 14, and $7 \mathrm{~d}$ before expected calving, and day of calving, and 1, 3, 5, 7, and $14 \mathrm{~d}$ postpartum. Fecal samples were divided into allocations of approximately $1 \mathrm{~g}$ of feces placed into sterile WhirlPak bags (Nasco, Fort Atkinson, WI). Fecal samples were analyzed quantitatively for coliform bacteria and Clostridium perfringens and qualitatively for E. coli O157:H7 and Salmonella. Coliform bacteria, E. coli O157:H7, and Salmonella were analyzed at the Washington State University Field Disease Investigative Unit laboratory (Pullman, WA). The E. coli O157:H7 and Salmonella were reported on a presence/absence basis and the coliforms were reported quantitatively as cfu/ $\mathrm{mL}$. Coliforms were counted and then log-transformed. If $C$. perfringens were present in a sample, the sample was genotyped at the Washington Animal Disease and Diagnostics Laboratory (Pullman, WA). The Washington Animal Disease and Diagnostics Laboratory assigned each fecal sample as "low, moderate, many, or very many" and data were then coded to be $1,2,3$, or 4 , respectively, for statistical analyses.

Table 2. Lactating TMR for control (CON) and Celmanax (EHY) treatments

\begin{tabular}{|c|c|c|}
\hline Item, $\%$ of $\mathrm{DM}$ & $\mathrm{CON}$ & $\mathrm{EHY}$ \\
\hline Alfalfa hay & 24.02 & 24.02 \\
\hline Corn silage & 23.20 & 23.20 \\
\hline Grain mix & 22.00 & 22.00 \\
\hline Steam rolled corn & 10.16 & 10.16 \\
\hline Whole cottonseed & 5.06 & 5.06 \\
\hline Dried distillers grains & 5.06 & 5.06 \\
\hline Grass hay & 4.64 & 4.64 \\
\hline \multicolumn{3}{|l|}{ Grain mix } \\
\hline Ground barley & 55.79 & 55.30 \\
\hline Soybean meal, $38 \%$ CP & 27.66 & 27.68 \\
\hline Macro-mineral mix ${ }^{1}$ & 15.17 & 15.17 \\
\hline Vitamin/trace mineral $\operatorname{mix}^{2}$ & 1.38 & 1.38 \\
\hline Celmanax $^{3}$ & 0.00 & 0.46 \\
\hline
\end{tabular}

${ }^{1}$ Consisted of (\% DM) Megalac (Arm and Hammer Animal Nutrition, Princeton, NJ), 34.65; sodium bicarbonate, 24.75; calcium carbonate, 21.29; salt, 7.43; Magox (Baymag Inc., Calgary, BC, Canada), 3.96; dicalciun phosphate, 2.48; Smartamine (Adisseo, Alpharetta, GA), 0.5; mineral oil, 4.95.

${ }^{2}$ Consisted of (\% DM) rice hulls, 29.39; limestone, 29.39; ManPro 80 (Zinpro Corporation, Eden Prairie, MN), 11.76; ZinPro 120 (Zinpro Corporation), 5.88; Zin 4-Plex C (Zinpro Corporation), 4.70; vitamin E 50\%, 2.94; $\mathrm{ZnSO}_{4}, 2.94 ; \mathrm{MnSO}_{4}, 2.94$; Sel-Plex (Zinpro Corporation), 2.35; CuPLEX 100 (Zinpro Corporation), 2.35; vitamin $\mathrm{D}_{3}, 2.35$; mineral oil, 1.76; $\mathrm{CuSO}_{4}$, 0.59; vitamin A, 0.35; Selenium 1\%, 0.29.

${ }^{3}$ Arm and Hammer Animal Nutrition (Princeton, NJ). 
Cows were milked twice daily (1100 and $2300 \mathrm{~h}$ ). Once each week, a.m. and p.m. milk samples were collected using Dairy Herd Improvement sampling equipment and analyzed for fat, protein, SCC, urea nitrogen, SNF, and lactose at Rocky Mountain DHIA (North Logan, UT). Values for AM and PM milk samples were averaged. Milk fat, protein, lactose, and SNF were analyzed using a Bentley2000 (Bentley Instruments Inc., Chaska, MN), and urea nitrogen was analyzed using a ChemSpec150 (Bentley Instruments Inc.). SomaCount FC (Bentley Instruments Inc.) was used to analyze SCC. The equation used to calculate log linear score of SCC was $[\ln (\mathrm{SCC}) / 0.6931]-3.6439$.

Blood samples were collected via coccygeal venipuncture during wk 1, 2, and 3 of lactation before the morning milking. Samples were analyzed for BHB concentration using a BHBCheck (PortaCheck, Moorestown, NJ).

Cows were visually observed daily throughout the first 60 DIM for presence of abnormal vaginal discharge. Data from activity monitor ear tags (CowManager, CowManager B.V. Harmelen, the Netherlands), and visual observation (twice daily) were used to detect estrus through 100 DIM. Data from DairyComp305 (Valley Ag Software, Tulare, CA) were used to calculate DIM at first estrus, days to first service, and number of services by 100 DIM.

To determine days to first ovulation/silent heat, milk samples were collected and tested for milk progesterone (P4) using a P4 Rapid (St Briavels, Gloucestershire, UK). Samples were obtained starting at 11 DIM and collected every other day until P4 was shown to be present in milk.

\section{Statistical Analyses}

Data were analyzed as a randomized complete block design with repeated measurements using the MIXED procedure of SAS version 9.4 (SAS Institute Inc., Cary, NC). The model included the fixed effects of treatment, week, covariate, and treatment $\times$ week, block, and the random effect of block. Week was the repeated variable and cow was the subject. Various error covariance structures were considered, but the structure with the lowest Akaike information criterion value was used.

Reproductive parameters were analyzed using the GLM procedure of SAS version 9.4 (SAS Institute Inc.). The Tukey option of PROC GLM was used to compare least squares means among treatments.

Milk pathogen data were analyzed using the FREQ procedure of SAS version 9.4 (SAS Institute Inc.). A chi-squared test was used to test the significance of treatment on pathogen presence and frequency of new IMI.

\section{RESULTS}

The descriptive characteristics of treatment groups were similar between treatment groups: average lactation number, $3.5 \pm 0.2( \pm \mathrm{SE})$ and $2.9 \pm 0.2$; average days dry, $59 \pm 4$ and $52 \pm 2$; average days in close-up, $25 \pm 1$ and $22 \pm 1$; and average PTA for milk, $787 \pm 84$ and $775 \pm 69$, respectively, for CON and EHY.

\section{Feed Composition}

The nutrient composition of the close-up and lactating diets are summarized in Tables 3 and 4, respectively. On average, the DCAD in the close-up diets was about $3 \mathrm{mEq} / 100 \mathrm{~g}$ lower in the EHY diet than the CON diet. All other parameters were similar.

\section{Dry Matter Intake and Feed Efficiency}

Prepartum and postpartum intake were not affected $(P>0.05)$ by treatment (Table 5). Prepartum, EHY

Table 3. Nutrient content of CON and EHY close-up diets ${ }^{1}$

\begin{tabular}{|c|c|c|}
\hline $\begin{array}{l}\text { Item, } \% \text { of DM unless } \\
\text { otherwise indicated }\end{array}$ & $\begin{array}{l}\text { CON } \\
\text { close-up }\end{array}$ & $\begin{array}{l}\text { EHY } \\
\text { close-up }\end{array}$ \\
\hline No. of samples & 6 & 6 \\
\hline DM & $50.3 \pm 0.7$ & $50.6 \pm 0.7$ \\
\hline $\mathrm{CP}$ & $17.7 \pm 0.9$ & $17.8 \pm 0.8$ \\
\hline Adjusted protein & $17.7 \pm 0.9$ & $17.8 \pm 0.8$ \\
\hline Soluble protein & $4.7 \pm 0.3$ & $4.6 \pm 0.6$ \\
\hline NDF protein & $2.1 \pm 0.3$ & $2.2 \pm 0.3$ \\
\hline $\mathrm{ADF}$ & $24.8 \pm 0.9$ & $24.8 \pm 0.4$ \\
\hline $\mathrm{NDF}$ & $37.8 \pm 1.6$ & $38.6 \pm 1.2$ \\
\hline Lignin & $4 \pm 0.2$ & $4.1 \pm 0.1$ \\
\hline $\begin{array}{l}\text { Ethanol soluble } \\
\text { carbohydrate (sugar) }\end{array}$ & $3.7 \pm 0.5$ & $3.9 \pm 0.5$ \\
\hline Starch & $16.3 \pm 0.8$ & $15.6 \pm 0.7$ \\
\hline Crude fat & $2.4 \pm 0.2$ & $2.3 \pm 0.2$ \\
\hline Ash & $11 \pm 0.3$ & $11.1 \pm 0.5$ \\
\hline Calcium & $1.48 \pm 0.09$ & $1.44 \pm 0.09$ \\
\hline Phosphorus & $0.47 \pm 0.01$ & $0.48 \pm 0.01$ \\
\hline Magnesium & $0.55 \pm 0.02$ & $0.58 \pm 0.01$ \\
\hline Potassium & $1.78 \pm 0.09$ & $1.8 \pm 0.09$ \\
\hline Sulfur & $0.36 \pm 0.01$ & $0.37 \pm 0.01$ \\
\hline Sodium & $0.08 \pm 0.01$ & $0.08 \pm 0$ \\
\hline Chloride & $1.24 \pm 0.07$ & $1.32 \pm 0.07$ \\
\hline Iron, $\mathrm{mg} / \mathrm{kg}$ & $400 \pm 44$ & $378 \pm 31$ \\
\hline Manganese, $\mathrm{mg} / \mathrm{kg}$ & $142 \pm 6$ & $146 \pm 8$ \\
\hline Zinc, $\mathrm{mg} / \mathrm{kg}$ & $148 \pm 28$ & $141 \pm 14$ \\
\hline Copper, $\mathrm{mg} / \mathrm{kg}$ & $22 \pm 2$ & $21 \pm 1$ \\
\hline TDN & $64.8 \pm 0.7$ & $64.3 \pm 0.5$ \\
\hline $\mathrm{NE}_{\mathrm{L}},{ }^{2} \mathrm{Mcal} / \mathrm{kg}$ & $1.45 \pm 0.02$ & $1.43 \pm 0.02$ \\
\hline $\mathrm{NFC}^{2}$ & $33.3 \pm 1$ & $32.4 \pm 1.6$ \\
\hline $\mathrm{NSC}^{2}$ & $20 \pm 0.5$ & $19.5 \pm 0.3$ \\
\hline DCAD, $\mathrm{mEq} / 100 \mathrm{~g}$ of $\mathrm{DM}$ & $-8.2 \pm 2.1$ & $-11.1 \pm 1.4$ \\
\hline
\end{tabular}

${ }^{1}$ Results are mean $\pm \mathrm{SE}$. CON $=$ diet without Celmanax (Arm and Hammer Animal Nutrition, Princeton, NJ) supplementation; EHY = diet with Celmanax at $56 \mathrm{~g} / \mathrm{d}$ during the close-up period and $28 \mathrm{~g} / \mathrm{d}$ during lactation.

${ }^{2}$ Calculated. 
cows consumed an average of $16.4 \mathrm{~kg} / \mathrm{d}$ and CON cows consumed $15.9 \mathrm{~kg} / \mathrm{d}$. Dry matter intake was affected by week and decreased over time prepartum $(P<0.0001)$, whereas it increased over time postpartum. Feed efficiency, calculated as kilograms of ECM/kilograms of DMI, decreased over time $(P<0.0001)$, but was not different between treatments: EHY averaged $1.84 \pm 0.1$ $\mathrm{kg}$ of ECM $/ \mathrm{kg}$ of DMI and CON averaged $1.90 \pm 0.1 \mathrm{~kg}$ of ECM $/ \mathrm{kg}$ of DMI $(P>0.05)$. No treatment by week interaction was observed $(P>0.05$; Table 7$)$.

\section{Body Condition Score and Body Weight}

Prepartum and postpartum BCS were not affected $(P>0.05)$ by treatment (Table 5). Prepartum and postpartum average BCS for CON were 3.15 and 2.63, whereas BCS for EHY were 3.17 and 2.73, respectively. Body condition was affected by time $(P<0.0001)$. Body condition score increased during the dry period,

Table 4. Nutrient content of CON and EHY lactating diets ${ }^{1}$

\begin{tabular}{|c|c|c|}
\hline $\begin{array}{l}\text { Item, } \% \text { of DM unless } \\
\text { otherwise indicated }\end{array}$ & $\begin{array}{c}\mathrm{CON} \\
\text { lactating }\end{array}$ & $\begin{array}{c}\text { EHY } \\
\text { lactating }\end{array}$ \\
\hline No. of samples & 7 & 7 \\
\hline $\mathrm{DM}$ & $49.6 \pm 0.4$ & $50.3 \pm 0.5$ \\
\hline $\mathrm{CP}$ & $17.7 \pm 0.2$ & $18 \pm 0.3$ \\
\hline Adjusted protein & $17.7 \pm 0.2$ & $18 \pm 0.3$ \\
\hline Soluble protein & $5 \pm 0.3$ & $5.3 \pm 0.4$ \\
\hline $\mathrm{ADF}$ protein & $1.3 \pm 0.1$ & $1.4 \pm 0.1$ \\
\hline NDF protein & $2.6 \pm 0.5$ & $3 \pm 0.5$ \\
\hline $\mathrm{ADF}$ & $22.2 \pm 0.5$ & $22.5 \pm 0.8$ \\
\hline Ash-free NDF & $36.1 \pm 1.1$ & $35.6 \pm 1.1$ \\
\hline Lignin & $4.2 \pm 0.1$ & $4.4 \pm 0.2$ \\
\hline $\begin{array}{l}\text { Ethanol-soluble } \\
\text { carbohydrate (sugar) }\end{array}$ & $2.5 \pm 0.4$ & $2.1 \pm 0.5$ \\
\hline Starch & $23.9 \pm 0.6$ & $24.6 \pm 0.7$ \\
\hline Ether extract & $3.2 \pm 0.3$ & $3.3 \pm 0.2$ \\
\hline Ash & $8.4 \pm 0.2$ & $8.4 \pm 0.1$ \\
\hline Calcium & $1.03 \pm 0.02$ & $0.98 \pm 0.01$ \\
\hline Phosphorus & $0.42 \pm 0.01$ & $0.43 \pm 0.01$ \\
\hline Magnesium & $0.34 \pm 0.01$ & $0.33 \pm 0.01$ \\
\hline Potassium & $1.76 \pm 0.03$ & $1.77 \pm 0.02$ \\
\hline Sulfur & $0.28 \pm 0.01$ & $0.28 \pm 0.01$ \\
\hline Sodium & $0.48 \pm 0.02$ & $0.49 \pm 0.02$ \\
\hline Chloride & $0.43 \pm 0.01$ & $0.42 \pm 0.01$ \\
\hline Iron, $\mathrm{mg} / \mathrm{kg}$ & $326 \pm 13$ & $360 \pm 31$ \\
\hline Manganese, $\mathrm{mg} / \mathrm{kg}$ & $102 \pm 3$ & $90 \pm 14$ \\
\hline Zinc, $\mathrm{mg} / \mathrm{kg}$ & $114 \pm 2$ & $115 \pm 3$ \\
\hline Copper, mg/kg & $25 \pm 1$ & $25 \pm 1$ \\
\hline TDN & $68.8 \pm 0.7$ & $68.9 \pm 0.4$ \\
\hline $\mathrm{NE}_{\mathrm{L}},{ }^{2} \mathrm{Mcal} / \mathrm{kg}$ & $1.54 \pm 0.02$ & $1.54 \pm 0.02$ \\
\hline $\mathrm{NFC}^{2}$ & $37.2 \pm 0.6$ & $36.2 \pm 1.3$ \\
\hline $\mathrm{NSC}^{2}$ & $26.4 \pm 0.5$ & $26.7 \pm 0.8$ \\
\hline DCAD, $\mathrm{mEq} / 100 \mathrm{~g}$ of $\mathrm{DM}$ & $36.5 \pm 1$ & $36.7 \pm 0.6$ \\
\hline
\end{tabular}

${ }^{1}$ Results are mean $\pm \mathrm{SE}$. CON $=$ diet without Celmanax $($ Arm and Hammer Animal Nutrition, Princeton, NJ) supplementation; EHY = diet with Celmanax at $56 \mathrm{~g} / \mathrm{d}$ during the close-up period and $28 \mathrm{~g} / \mathrm{d}$ during lactation.

${ }^{2}$ Calculated. began to decrease at close-up, and continued to decrease throughout 8 wk postpartum. Prepartum and postpartum BW was not affected by treatment $(P<$ 0.05; Table 5). Body weight increased between 3 and 1 wk before parturition but began to decrease postpartum $(P<0.0001)$ and throughout the first 8 wk of lactation.

\section{Milk Yield}

Milk yield and composition are summarized in Table 5. Cows fed the CON diet tended $(P<0.10)$ to have higher milk yield $(49.3 \pm 1.9 \mathrm{~kg} / \mathrm{d})$ than cows fed the EHY diet $(46.0 \pm 1.9 \mathrm{~kg} / \mathrm{d})$. Milk yield increased over time for both groups $(P<0.0001)$ with no treatment by week interaction $(P>0.05)$. The interaction between treatment and week was significant for ECM $(P$ $=0.0017$ ). During wk 1 and 2, ECM for cows fed EHY diet was greater and for wk 3 through 8, ECM for cows fed CON diet was greater. Fat-corrected milk (4\%) increased over time $(P<0.05)$ but was not different $(P$ $>0.05)$ between treatments, and no treatment by week interaction was observed $(P=0.54)$.

\section{Milk Components}

Milk components are summarized in Table 5 and Figure 1. No difference in CON (24.27\% IgG) or EHY $(24.28 \% \mathrm{IgG})$ colostrum quality $(P>0.05)$ was observed. Milk fat concentration was greater $(P<0.05)$ for EHY than CON (4.03 $\pm 0.17 \%$ vs. $3.74 \pm 0.17 \%)$, and milk fat yield was not affected by treatment $(P$ $=0.95)$ or treatment by week interaction. Milk protein concentration was primarily affected by diet and greater $(P=0.0003)$ for EHY $(3.30 \pm 0.05)$ than CON $(3.11 \pm 0.05 \%)$. In addition, there was a treatment by week interaction for milk protein concentration (Figure 2 ) with variable differences over the 8 wk. Milk protein yield was not affected by $\operatorname{diet}(P<0.71)$, but a significant treatment by week interaction was observed with protein yield lower for CON than EHY at the beginning and increasing to be greater than EHY by the end of the 8 -wk study. There were no treatment differences $(P>0.05)$ for MUN with averages of 11.8 $\pm 0.35 \mathrm{mg} / \mathrm{dL}$ for $\mathrm{CON}$ and $11.5 \pm 0.35 \mathrm{mg} / \mathrm{dL}$ for EHY. Lactose concentration was not different between treatments. Solids-not-fat concentration was greater $(P$ $=0.0017)$ for $\mathrm{EHY}(9.19 \pm 0.06)$ than CON $(8.99 \pm$ $0.06 \%)$. There was an interaction $(P<0.03)$ of treatment by week for yield of SNF with similar yields in wk 1 and 2, and a trend for increased yield of SNF for CON at various weeks after wk 3. Lactose concentration and yield were not affected by diet. 
Table 5. Summary of prepartum DMI and postpartum BW, BCS, DMI, milk yield, milk composition, and feed efficiency ${ }^{1}$

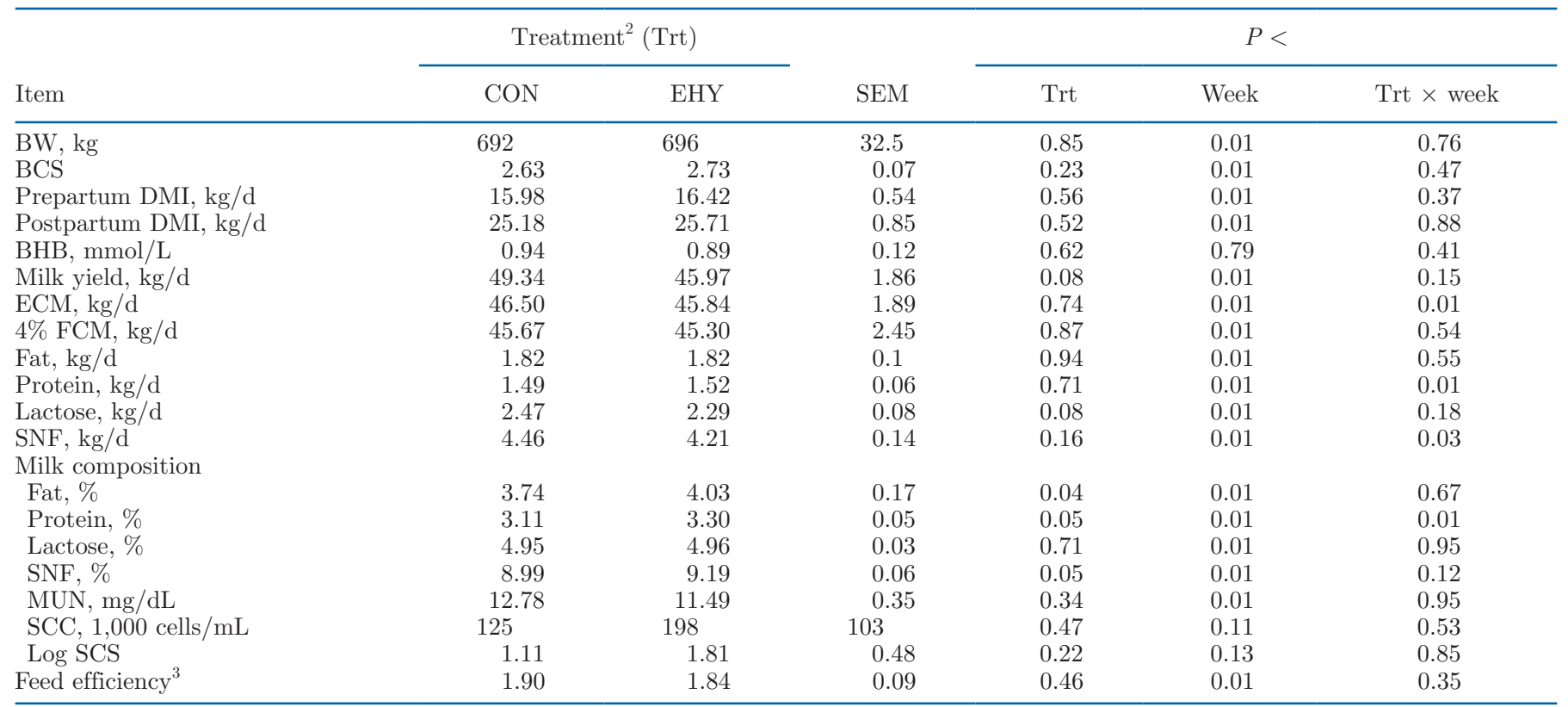

${ }^{1}$ All data except BCS were collected on a weekly basis; BCS was collected every other week.

${ }^{2} \mathrm{CON}=$ diet without Celmanax (Arm and Hammer Animal Nutrition, Princeton, NJ) supplementation; EHY = diet with Celmanax at 56 g/d during the close-up period and $28 \mathrm{~g} / \mathrm{d}$ during lactation.

${ }^{3}$ Calculated as $\mathrm{kg}$ of ECM/ $\mathrm{kg}$ of DMI.

\section{Udder Health}

Somatic cell count was not different between treatments regardless of the units of expression (Table 5). Somatic cell count of EHY treated cows averaged 198 $\pm 103 \mathrm{cell} / \mathrm{mL}$ and $\mathrm{CON}$ averaged $125 \pm 103$ cells/ $\mathrm{mL}(P>0.05)$, were not affected by week $(P>0.05)$, and there was no treatment by week interaction $(P>$ 0.05). When the SCC was transformed to the log linear SCS, no differences were detected between treatments or week, no treatment by week interaction was detected $(P>0.05$; Table 5$)$.

At the time of dry-off (initiation of the study), the prevalence of Pseudomonas sp., Staphylococcus sp., esculin Streptococcus, Streptococcus uberis, Bacillus, Pasturella, Proteus, and IMI was not different among treatments $(P>0.05)$. At calving (colostrum), no treatment differences $(P>0.05$, Table 6$)$ were observed in Pseudomonas sp., esculin Streptococcus, Staphylococcus sp., Klebsiella, E. coli, Bacillus, S. uberis, or total IMI. No treatment differences were detected for the prevalence of Pseudomonas sp., esculin Streptococcus, Staphylococcus sp., Klebsiella, E. coli, Bacillus, S. uberis, or total IMI during the first $3 \mathrm{wk}$ of lactation (Table 6). However, in the third week of lactation the EHY group had more cows $(16 ; P=$ 0.05) infected with Staphylococcus sp. than CON cows (10 cows).
The total new intramammary quarter infections were not different $(P>0.05)$ between the CON (99 infections) and EHY (97 infections) groups throughout the first week of lactation. New coliform infections were not different $(P=0.05)$ in the CON (14 infections) or EHY (26 infections) groups.

\section{$\beta-H y d r o x y b u t y r a t e$}

$\beta$-Hydroxybutyrate was not different between treatments or wk $(P>0.05)$ and did not have a treatment by week interaction $(P>0.05)$. The average concentration of BHB for both CON $(0.94 \pm 0.09 \mathrm{mmol} / \mathrm{L})$ and EHY $(0.89 \pm 0.09 \mathrm{mmol} / \mathrm{L})$ remained below subclinical concentrations $(<1.2 \mathrm{mmol} / \mathrm{L})$.

\section{Reproductive Parameters}

No treatment difference was observed for DIM at first ovulation (CON and $\mathrm{EHY}=25 ; P>0.05)$; however, DIM at first standing heat was significantly less $(P=$ 0.003) for EHY cows (30 DIM) than for CON cows (51 DIM).

\section{Fecal Pathogens}

Clostridium perfringens type A was present in 259 of 266 fecal samples. During the prepartum period, the 


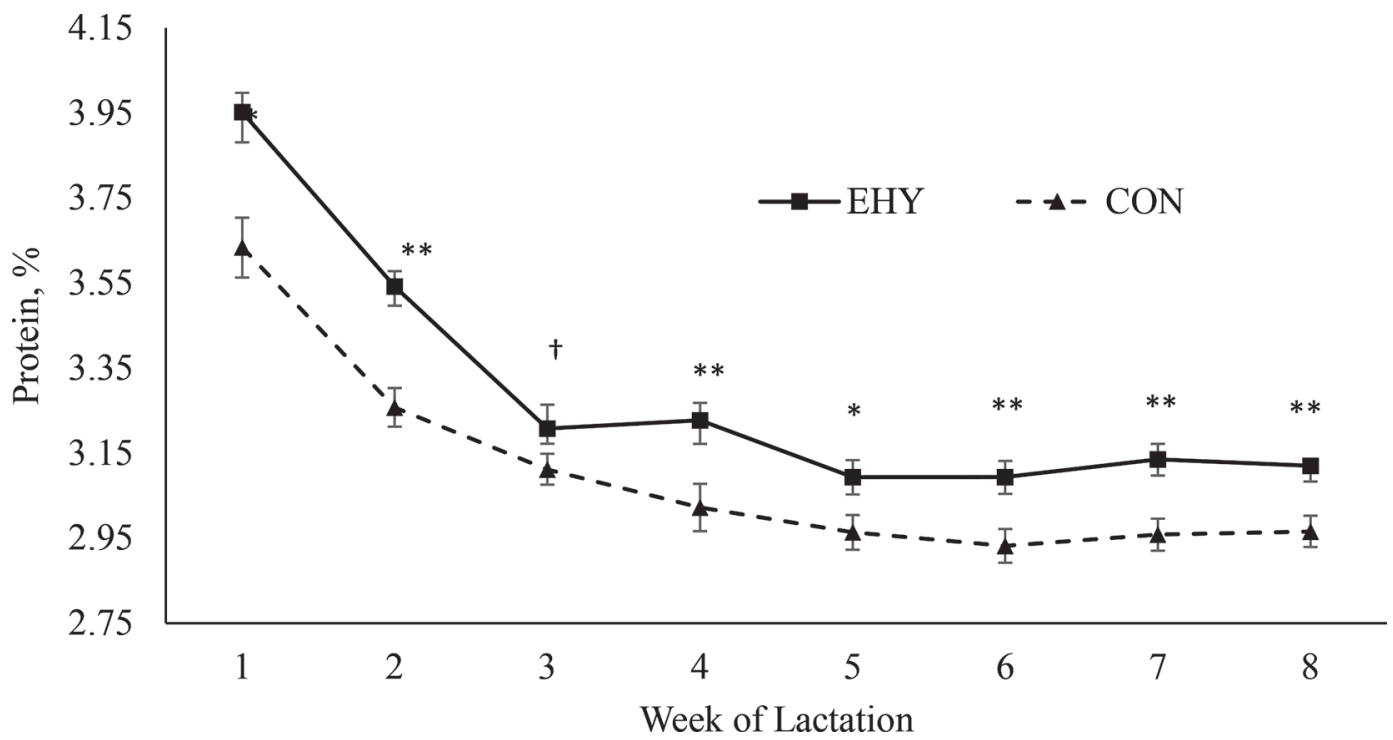

Figure 1. Mean weekly milk protein concentration. CON = diet without Celmanax (Arm and Hammer Animal Nutrition, Princeton, NJ) supplementation; EHY = diet with Celmanax at $56 \mathrm{~g} / \mathrm{d}$ during the close-up period and $28 \mathrm{~g} / \mathrm{d}$ during lactation. Treatment: $P=0.0003$, week: $P<0.001$, treatment $\times$ week: $P=0.0024 . \dagger P<0.1,{ }^{*} P<0.05,{ }^{*} P<0.01$. Error bars are SE.

presence of $C$. perfringens in feces was not different between treatments but did increase as parturition neared $(P=0.0002)$; no treatment by week interaction was observed (Figure 2). During the postpartum period, $C$. perfringens tended to have a greater presence $(P<0.08)$ in CON cows $(1.91 \pm 0.2)$ than in EHY cows $(1.67 \pm 0.2)$. Clostridium perfringens decreased over time $(P=0.003)$; no treatment $\times$ sampling time interaction was observed.

Coliforms were found in every fecal sample collected. There was no treatment effect $(P>0.05)$ on total coliforms. Total coliforms increased as parturition neared $(P=0.01)$, but no treatment $\times$ day interaction was observed.

Escherichia coli $\mathrm{O} 157: \mathrm{H} 7$ was present in 4 of the 328 samples collected. Of the 4 positive samples, 3 were from 3 different CON cows at $-14,-7$, and 5 DIM. The positive sample from the EHY cow was at the first sampling -21 DIM, and was therefore not associated with treatment.

Salmonella was present in 7 of the 328 samples collected. Six of the 7 positive samples were collected from CON cows. One control cow had Salmonella present in 3 consecutive samples, $-7,0$, and 1 DIM. Two of the positive samples came from the same cow at -21 and -7 DIM. The last positive CON sample was from a separate cow (5 DIM), but a cow that also had E. coli O157:H7 at a different sampling period ( -7 DIM). The positive EHY sample came from a sample collected on the day of calving.

\section{Health Events}

Health events are summarized in Table 7 . Three cows from each treatment had milk fever upon calving. Three EHY cows and 2 CON cows had a retained placenta. Three cows from each treatment had metritis and one CON cow developed endometritis. One cow from each treatment was treated for a displaced abomasum. During the first 3 wk of lactation, 2 EHY cows and 1 CON cow tested positive for clinical ketosis. The occurrence of subclinical ketosis was greater $(P<0.05)$ in the CON group (9 cows) that in the EHY group (3 cows). The 3 cows that tested positive for clinical ketosis did not show any clinical signs. Two control cows were euthanized at 66 and 71 DIM, 6 and $11 \mathrm{~d}$ after being returned to the general herd diet. Necropsy results showed hemorrhagic bowel syndrome for both.

\section{DISCUSSION}

During the transition period cows undergo metabolic and immunological stress, as well as a compromised ability to fight infectious diseases. Limited studies have shown that yeast culture or yeast cell components have a positive effect on immune response (Heinrichs et al., 2003; Franklin et al., 2005). Yeast culture has been shown to improve rumen health by increasing rumen pH (Stewart et al., 1997; Chaucheyras-Durand et al., 2012). In this study, we evaluated if supplementation of Celmanax, a yeast culture and hydrolyzed yeast prod- 
Table 6. Summary of incidence of IMI and new IMI in the control (CON) and Celmanax (EHY) treatments ${ }^{1}$

\begin{tabular}{|c|c|c|c|c|c|c|c|c|c|c|}
\hline Item & \multicolumn{2}{|c|}{ Dry off } & \multicolumn{2}{|c|}{ Fresh } & \multicolumn{2}{|c|}{ Wk 1} & \multicolumn{2}{|c|}{ Wk 2} & \multicolumn{2}{|c|}{ Wk 3} \\
\hline Psuedomonas sp. & $10^{2}$ & 5 & 0 & 6 & 5 & 0 & 5 & 10 & 0 & 0 \\
\hline Staphylococcus sp. & 65 & 90 & 70 & 59 & 55 & 60 & 55 & 40 & $50^{3}$ & $80^{3}$ \\
\hline Klebsiella & 0 & 0 & 0 & 6 & 10 & 20 & 20 & 10 & 0 & 10 \\
\hline Escherichia coli & 0 & 0 & 12 & 6 & 5 & 0 & 15 & 10 & 5 & 0 \\
\hline Serratia & 0 & 0 & 0 & 0 & 0 & 0 & 0 & 5 & 0 & 10 \\
\hline Pastuerella & 0 & 5 & 0 & 0 & 0 & 0 & 10 & 15 & 0 & 5 \\
\hline Proteus & 5 & 0 & 0 & 0 & 0 & 0 & 0 & 0 & 0 & 0 \\
\hline New IMI & - & - & 76 & 82 & 95 & 90 & 0 & 5 & 85 & 95 \\
\hline
\end{tabular}

${ }^{1} \mathrm{CON}=$ diet without Celmanax (Arm and Hammer Animal Nutrition, Princeton, NJ) supplementation; EHY = diet with Celmanax at $56 \mathrm{~g} / \mathrm{d}$ during the close-up period and $28 \mathrm{~g} / \mathrm{d}$ during lactation.

${ }^{2}$ Incidence or $\%$ occurrence.

${ }^{3} P=0.05$.

uct, would have an effect on DMI, disease and disorder prevalence, milk production and quality, reproductive parameters, and pathogen shedding in feces and milk.

Previous studies have shown that the effect of feeding yeast cultures on production performance varies (Robinson and Garrett, 1999; Soder and Holden, 1999; Nocek et al., 2011; Yuan et al., 2015a,b). The response to yeast culture has been suggested to be dependent on factors such as stage of lactation, composition of feed, environmental conditions, and dosage of the supplement (Piva et al., 1993; Yuan et al., 2015a).

\section{Dry Matter Intake, Body Condition Score, Body Weight, Feed Efficiency, and Milk Production Performance}

Dann et al. (2000) and Ramsing et al. (2009) reported that supplementation of yeast culture during

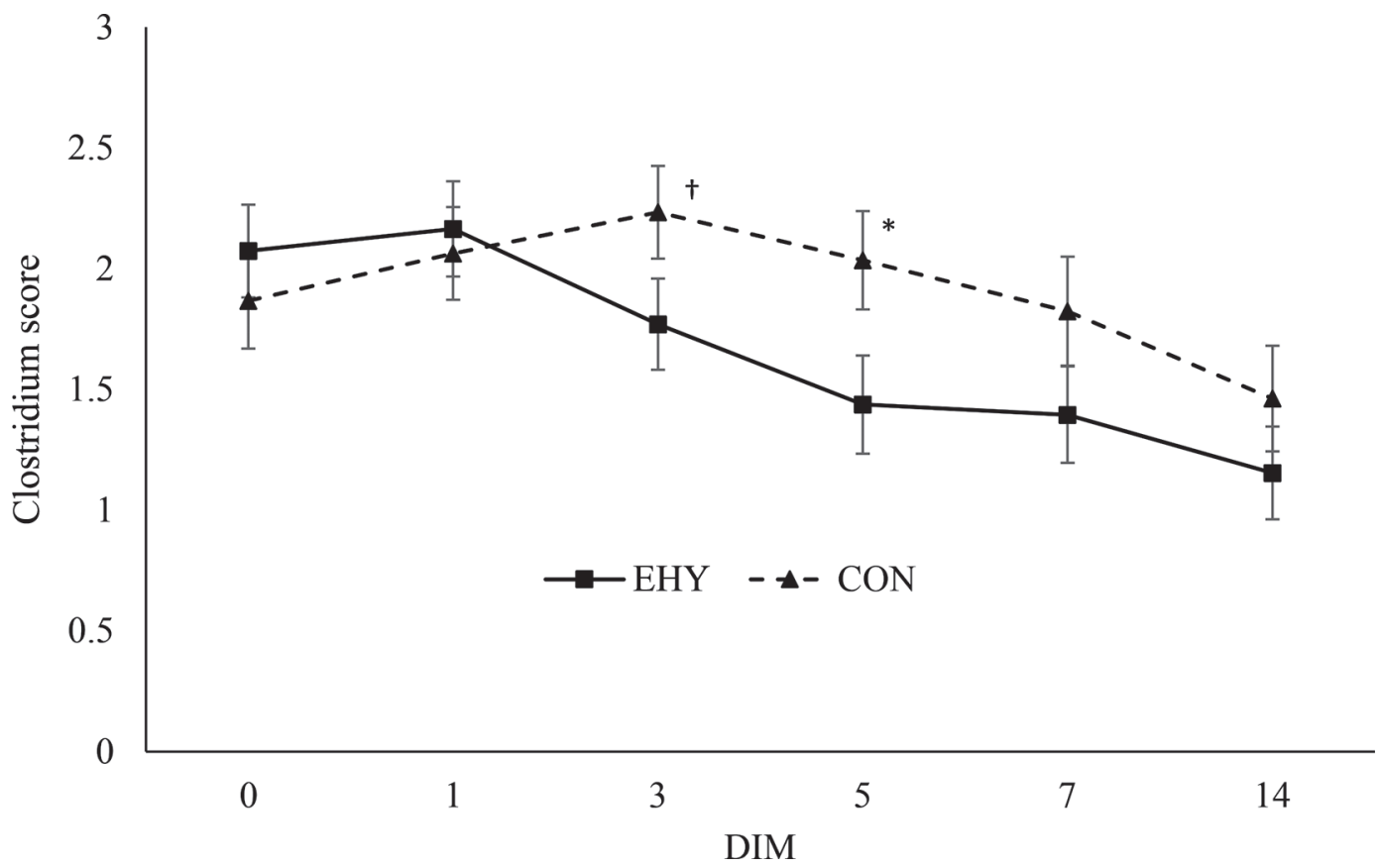

Figure 2. Mean daily (0-14 DIM) clostridium score (1-4 basis adapted from laboratory; few, moderate, many, and very many, respectively). $\mathrm{CON}=$ diet without Celmanax (Arm and Hammer Animal Nutrition, Princeton, NJ) supplementation; EHY = diet with Celmanax at $56 \mathrm{~g} / \mathrm{d}$ during the close-up period and $28 \mathrm{~g} / \mathrm{d}$ during lactation. Treatment trend: $P=0.08$, day: $P=0.0027$, treatment $\times$ day: $P=0.3040$. $\dagger P<0.1$, $* P<0.05$. Error bars are SE. 
the transition period significantly increased prepartum DMI in cows, and Dann et al. (2000) observed that it also increased DMI postpartum. No treatment effects on DMI were observed in the current study in the prepartum or postpartum period, which is in agreement with the findings of Soder and Holden (1999) and Yuan et al. (2015a). Harrison et al. (1988) concluded that supplementation of yeast culture to lactating dairy cows increased total cellulolytic bacteria concentration; however, it did not increase DMI. Feed efficiency (ECM, $\mathrm{kg} / \mathrm{kg}$ ) was not different between treatments, similar to the results of Yuan et al. (2015a). Our observation of a lack of difference in milk yield, ECM yield, and FCM yield are in agreement with other studies (Arambel and Kent, 1990; Soder and Holden, 1999; Dann et al., 2000; Yuan et al., 2015a). However, Nocek et al. (2011) found that ECM production increased with the supplementation of Celmanax. We observed a greater milk fat concentration in EHY cows, which agrees with Yuan et al. (2015a). However, other studies have found no effect on milk fat concentration in cows fed yeast culture (Arambel and Kent, 1990; Soder and Holden, 1999; Dann et al., 2000). Arambel and Kent (1990) speculated that the lack of difference in milk fat concentration may be indicative that the ADF provided from the diet was likely sufficient to maintain milk fat synthesis and that the yeast culture did not change fatty acid synthesis. The lack of difference in milk fat production in our study can be attributed to the trend for increased milk yield for CON, resulting in equal yield of milk fat. In this study, milk protein concentration of EHY cows was greater in all weeks except one. Nocek et al. (2011) did not observe an increase in milk protein concentration when cows were supplemented with yeast culture alone.

Table 7. Summary of health events ${ }^{1}$

\begin{tabular}{lcr}
\hline Incidence, $\%$ & CON & EHY \\
\hline Milk fever & $15^{2}(3)^{3}$ & $15(3)$ \\
Retained placenta & $10(2)$ & $15(3)$ \\
Metritis & $10(2)$ & $15(3)$ \\
Endometritis & $5(1)$ & $0(0)$ \\
Clinical mastitis & $10(2)$ & $10(2)$ \\
Displaced abomasum & $5(1)$ & $5(1)$ \\
Subclinical ketosis & $50(10)$ & $20(4)$ \\
Ketosis $^{4}$ & $5(1)$ & $10(2)$ \\
Euthanized $^{4}$ & $10(2)$ & $0(0)$ \\
\hline
\end{tabular}

${ }^{1} \mathrm{CON}=$ diet without Celmanax (Arm and Hammer Animal Nutrition, Princeton, NJ) supplementation; EHY = diet with Celmanax at 56 $\mathrm{g} / \mathrm{d}$ during the close-up period and $28 \mathrm{~g} / \mathrm{d}$ during lactation.

${ }^{2}$ Incidence.

${ }^{3}$ Number of animals out of 20 .

${ }^{4}$ Animals were diagnosed with hemorrhagic bowel syndrome postmortem.
It has been shown that cows supplemented with yeast culture have increased microbial nitrogen production per kilogram of digested DM (Miller-Webster et al., 2002). The increase in microbial protein production transported to the intestines could support the production of more milk protein (Nocek et al., 2011). Like milk fat production, lack of treatment difference in milk protein production can be attributed to lower overall milk production in EHY cows. Other studies have observed no treatment effects on MUN (Nocek et al., 2011; Yuan et al., 2015a). The average MUN in our study is consistent with what Nocek et al. (2011) found, a range of 11.1 to $11.4 \mathrm{mg} / \mathrm{dL}$. Several studies (Robinson and Garrett, 1999; Soder and Holden, 1999; Dann et al., 2000; Nocek et al., 2011; Yuan et al., 2015a) have also reported that lactose concentration was not affected by yeast culture supplementation. Robinson and Garrett (1999) found that lactose concentration increases over time. Yuan et al. (2015b) also fed Celmanax in the prepartum and postpartum period. Like the current study, they did not find differences in colostrum quality.

\section{Udder Health}

Similar to Yuan et al. (2015b), we did not see a difference in raw SCC or the linear SCC. In the first $8 \mathrm{wk}$ of lactation, Nocek et al. (2011) did not observe differences in SCC; however, in wk 8 to 14, cows supplemented with Celmanax had significantly lower SCC.

To our knowledge, this is the first study to look at yeast culture supplementation and presence of mastitis pathogens and new IMI. While the only statistical difference was an increased presence of Staphylococcus in EHY cows during the third week of lactation, it is important to note that there were only 2 total clinical cases of mastitis throughout the trial. In this study, an IMI was defined as the presence of a pathogen in a quarter but was not always considered subclinical mastitis. New IMI were evaluated by quarter and sampling period. Using the sample collected at dry off as a baseline, colostrum pathogens were compared with dry samples to determine new IMI; if the same pathogen appeared in the same quarter in the colostrum sample, it was considered an existing IMI. For an IMI to be considered "new," a minimum of 2 wk had to elapse without the presence of the specific pathogen. There were no differences in prevalence in new IMI; however, the CON and EHY cows were not housed separately.

None of the cows on the study were vaccinated for $E$. coli at dry-off or close-up; however, there were no clinical cases of E. coli mastitis. New IMI caused by coliform bacteria were evaluated because enzymatically hydrolyzed yeast has been shown to agglutinate $E$. coli. The 
EHY cows had numerically more new coliform infections than CON cows. However, it is important to note that, while there were more new coliform infections in EHY cows, coliform infections in CON appeared to be of longer duration. One CON cow had an E. coli infection that lasted from the colostrum sampling through the second week of lactation. The EHY cows cleared $E$. coli infections within 1 wk.

\section{Health Events}

In this study, subclinical ketosis was defined as 1.2 to $2.0 \mathrm{mmol} / \mathrm{L}$ where anything $>2.0 \mathrm{mmol} / \mathrm{L}$ was considered clinical ketosis. The average BHB concentration was not different between treatments and the average concentration during the first $3 \mathrm{wk}$ of lactation for each treatment was below subclinical concentration. Yuan et al. (2015a) found a quadratic dose effect of Celmanax; as dosage increased, BHB concentration also increased. Another result from their research was increased milk fat in the dosages with the highest BHB concentration, suggesting potential enhanced lipid metabolism. However, it is unlikely that yeast culture has a direct effect on lipid metabolism (Yuan et al., 2015a). In this study, there were no differences in DMI or BCS, which would suggest that cows were consuming similar amounts of energy and mobilizing fat at the same rate. Although the average BHB concentration was not different among treatments in this study, there were more CON cows with subclinical ketosis. The elevated BHB concentration in the CON cows suggests that they may have been in a more severe state of negative energy balance than EHY cows. This is consistent with the increased milk yield in CON cows.

Milk fever affected $15 \%$ of cows in each treatment. The average DCAD in the close-up diet may not have been low enough to prevent milk fever (DCAD being $-15 \mathrm{mEq} / 100 \mathrm{~g}$ of DM; Oetzel, 2000). The proportions of displaced abomasums in the present study and other studies were similar and no treatment effects were observed (Nocek et al., 2011; Yuan et al., 2015b).

The proportion of retained placentas in the present study was higher than the proportions of Nocek et al. (2011) and Yuan et al. (2015b). This could also be attributed to the DCAD in the close-up diet of this study. All cows (EHY and CON) with an observed retained placenta also developed metritis, but the incidence of metritis was not different among treatments, which is supported by other studies (Nocek et al., 2011; Yuan et al., 2015b). Yuan et al. (2015b) took uterine swabs of fresh cows to determine uterine health and inflammation by neutrophil populations; the researchers did not see differences between control cows and yeast supplemented cows. In the present study, one cow $(\mathrm{CON})$ was observed to have clinical endometritis. The prevalence of endometritis in the present study is numerically less than the findings of Yuan et al. (2015b); however, neither study showed treatment effects.

Somatic cell count and pathogen presence is an indicator of subclinical and clinical mastitis cases as well as an index for milk quality. In the present study, 2 clinical mastitis cases per treatment were observed, but throughout the duration of the study, SCC and linear SCS were not affected by treatment. These results suggest that yeast culture in this study did not affect udder health. Proudfoot et al. (2009) and Nocek et al. (2011) identified a relationship between yeast culture, SCC, and mastitis. Both studies saw a reduction in subclinical mastitis and number of new clinical cases of mastitis, defined the same as in the present study. However, it is important to note the proportion of clinical mastitis that Nocek et al. (2011) observed was 0.18 greater than the current study, 0.10 . This could potentially suggest that the overall udder health in the present study was better than that of other studies.

Two control cows were euthanized at 66 and 71 DIM and necropsy results showed hemorrhagic bowel syndrome. While cows were technically off-study at 60 DIM, it is easy to suggest that the hemorrhagic bowel syndrome may have been related to a lack of EHY since cows had not received their Clostridia vaccine (UltraChoice 8 ) at 3 to $4 \mathrm{wk}$ prepartum. Clostridium perfringens type A has been found in $85 \%$ of hemorrhagic bowel syndrome cases (Dennison et al., 2002).

\section{Reproductive Parameters}

Kalmus et al. (2009) also determined days to first ovulation utilizing $\mathrm{P} 4$; however, their average (36 DIM) was numerically higher than the present study (25 DIM). One difference between the 2 studies was frequency of sample collection; Kalmus et al. (2009) analyzed milk samples twice per week, whereas we collected samples every other day starting at 10 or 11 DIM. The most noteworthy reproductive parameter in the current study is the treatment difference in days to first estrus ( $\mathrm{EHY}=30, \mathrm{CON}=51)$. Days to first estrus was detected visually and by the CowManager system. Sexual behavior is driven by estrogen production from the dominant follicle. One potential explanation for the treatment difference of days to first estrus is an insulin effect on pre-ovulatory estrogen concentrations (AlIbrahim et al., 2010). AlIbrahim et al. (2010) found that cows supplemented with yeast culture had increased pre-ovulatory estrogen concentrations. Insulin concentration was not analyzed in this study but could be useful in the explanation of earlier days to first estrus in the EHY group. 


\section{Fecal Pathogens}

Clostridium perfringens type A can be found in the intestine of most warm-blooded animals as well as the environment and can cause enteric diseases. To our knowledge, this study is one of the first to look at $C$. perfringens shedding for cattle supplemented with yeast culture. We found that $C$. perfringens increased as parturition nears and tended to be higher in CON cows postpartum, but shedding rate was not different prepartum. Celmanax has been shown to reduce $E$. coli O157:H7 in beef feeder calves (Baines and Erb, 2013). In the present study, there were no differences in the presence of E. coli O157:H7. The prevalence of E. coli O157:H7 and Salmonella on the farm where the study was conducted was extremely low, so these results are not surprising. Enzymatic digestion does not break down MOS, a cell wall component liberated when yeast is enzymatically hydrolyzed in the small intestines of chickens (Spring et al., 2000), and bacteria agglutinated MOS such as Salmonella and E. coli could leave the intestine without causing disease. In this study, one EHY-treated cow had Salmonella present at the day of calving. The other 3 of the other 6 positive samples for Salmonella came from the same control cow at consecutive samplings, suggesting that Salmonella persisted in the gut of that cow, whereas the MOS from the yeast in supplement to EHY cows was able to agglutinate the Salmonella within the gut.

\section{CONCLUSIONS}

In the present study, it was observed that EHY did not affect feed intake, BW, BCS, milk production or component production, MUN, lactose concentration, BHB concentration, colostrum quality, presence of milk pathogens or IMI, SCC, days to first insemination, DIM at first ovulation, or health events within the transition period. However, we observed positive effects or tendencies for an increase in milk fat and protein concentration, SNF concentration, decreased days to first estrus, fewer Clostridium perfringens in the postpartum period, and numerically fewer cows shedding E. coli O157:H7 and Salmonella. The lack of differences in the present study may be attributed to the overall management and husbandry of the animals, and environmental conditions.

\section{ACKNOWLEDGMENTS}

Financial support provided by Church and Dwight Animal Nutrition (Princeton, NJ). The authors have no conflicts of interest.

\section{REFERENCES}

AlIbrahim, R. M., M. A. Crowe, P. Duffy, L. O'Grady, M. E. Beltman, and F. J. Mulligan. 2010. The effect of body condition at calving and supplementation with Saccharomyces cerevisiae on energy status and some reproductive parameters in early lactation dairy cows. Anim. Reprod. Sci. 121:63-71. https://doi.org/10.1016/j .anireprosci.2010.04.183.

Arambel, M. J., and B. A. Kent. 1990. Effect of yeast culture on nutrient digestibility and milk response in early to midlactation dairy cows. J. Dairy Sci. 73:1560-1563. https://doi.org/10.3168/ jds.S0022-0302(90)78825-X.

Baines, D., and S. Erb. 2013. Characterization of Shiga toxin-producing Escherichia coli infections in beef feeder calves and the effectiveness of a prebiotic in alleviating Shiga toxin-producing Escherichia coli infections. Ir. Vet. J. 66:17. https://doi.org/10 .1186/2046-0481-66-17.

Chaucheyras-Durand, F., E. Chevaux, C. Martin, and E. Forano. 2012. Use of yeast probiotics in ruminants: Effects and mechanisms of action on rumen $\mathrm{pH}$, fibre degradation, and microbiota according to the diet. Probiotic in Animals. IntechOpen. https:// doi.org/10.5772/50192.

Chaucheyras-Durand, F., and H. Durand. 2010. Probiotics in animal nutrition and health. Benef. Microbes 1:3-9. https://doi.org/10 .3920/BM2008.1002.

Chiquette, J. 1995. Saccharomyces cerevisiae and Aspergillus oryzae used alone or in combination, as a feed supplement for beef and dairy cattle. Can. J. Anim. Sci. 75:405-415. https://doi.org/10 .4141/cjas95-060.

Dann, H. M., J. K. Drackley, G. C. McCoy, M. F. Hutjens, and J. E. Garrett. 2000. Effects of yeast culture (Saccharomyces cerevisiae) on prepartum intake and postpartum intake and milk production of Jersey cows. J. Dairy Sci. 83:123-127. https://doi.org/10.3168/ jds.S0022-0302(00)74863-6.

Dennison, A. C., D. C. VanMetre, R. J. Callan, P. Dinsmore, G. L. Mason, and R. P. Ellis. 2002. Hemorrhagic bowel syndrome in dairy cattle: 22 cases (1997-2000). J. Am. Vet. Med. Assoc. 221:686-689. https://doi.org/10.2460/javma.2002.221.686.

Edmonson, A. J., I. J. Lean, L. D. Weaver, T. Farver, and G. Webster. 1989. A body condition scoring chart for Holstein dairy cows. J. Dairy Sci. 72:68-78. https://doi.org/10.3168/jds.S0022 $-0302(89) 79081-0$

Franklin, S. T., M. C. Newman, K. E. Newman, and K. I. Meek. 2005. Immune parameters of dry cows fed mannan oligosaccharide and subsequent transfer of immunity to calves. J. Dairy Sci. 88:766775. https://doi.org/10.3168/jds.S0022-0302(05)72740-5.

Goff, J. P. 2006. Major advances in our understanding of nutritional influences on bovine health. J. Dairy Sci. 89:1292-1301. https:// doi.org/10.3168/jds.S0022-0302(06)72197-X.

Grummer, R. R. 1995. Impact of changes in organic nutrient metabolism on feeding the transition dairy cow. J. Anim. Sci. 73:28202833. https://doi.org/10.2527/1995.7392820x.

Grummer, R. R., P. C. Hoffman, M. L. Luck, and S. J. Bertics. 1995 Effect of prepartum and postpartum dietary energy on growth and lactation of primiparous cows. J. Dairy Sci. 78:172-180. https:// doi.org/10.3168/jds.S0022-0302(95)76627-9

Harrison, G. A., R. W. Hemken, K. A. Dawson, R. J. Harmon, and K. B. Barker. 1988. Influence of addition of yeast culture supplement to diets of lactating cows on ruminal fermentation and microbial populations. J. Dairy Sci. 71:2967-2975. https://doi.org/10.3168/ jds.S0022-0302(88)79894-X.

Heinrichs, A. J., C. M. Jones, and B. S. Heinrichs. 2003. Effects of mannan oligosaccharide or antibiotics in neonatal diets on health and growth of dairy calves. J. Dairy Sci. 86:4064-4069. https://doi .org/10.3168/jds.S0022-0302(03)74018-1.

Hoffman, O. A., J. E. Standing, and A. H. Limper. 1993. Pneumocystis carinii stimulates tumor necrosis factor-alpha release from alveolar macrophages through a beta-glucan-mediated mechanism. J. Immunol. 150:3932-3940.

Kalmus, P., T. Orro, A. Waldmann, R. Lindjarv, and K. Kask. 2009. Effect of yeast culture on milk production and metabolic and re- 
productive performance of early lactation dairy cows. Acta Vet. Scand. 51:32. https://doi.org/10.1186/1751-0147-51-32.

Miller-Webster, T., W. H. Hoover, M. Holt, and J. E. Nocek. 2002. Influence of yeast culture on ruminal microbial metabolism in continuous culture. J. Dairy Sci. 85:2009-2014. https://doi.org/10 .3168/jds.S0022-0302(02)74277-X.

Nocek, J. E., M. G. Holt, and J. Oppy. 2011. Effects of supplementation with yeast culture and enzymatically hydrolyzed yeast on performance of early lactation dairy cattle. J. Dairy Sci. 94:40464056. https://doi.org/10.3168/jds.2011-4277.

Oetzel, G. R. 2000. Management of dry cows for the prevention of milk fever and other mineral disorders. Vet. Clin. North Am. Food Anim. Pract. 16:369-386. https://doi.org/10.1016/S0749 -0720(15)30110-9.

Pelan-Mattocks, L. S., M. E. Kehrli Jr., T. A. Casey, and J. P. Goff. 2000. Fecal shedding of coliform bacteria during the periparturient period in dairy cows. Am. J. Vet. Res. 61:1636-1638. https://doi .org/10.2460/ajvr.2000.61.1636.

Piva, G., S. Belladonna, G. Fusconi, and F. Sicbaldi. 1993. Effects of yeast on dairy cow performance, ruminal fermentation, blood components, and milk manufacturing properties. J. Dairy Sci. 76:27172722. https://doi.org/10.3168/jds.S0022-0302(93)77608-0.

Proudfoot, K., D. Weary, and M. von Keyserlink. 2009. The effect of enzymatically hydrolyzed yeast on feeding behavior and immune function in early lactation dairy cows. J. Dairy Sci. 91(Supp. 1):279. (Abstr.)

Ramsing, E. M., J. A. Davidson, P. D. French, I. Yoon, M. Keller, and H. Peters-Fleckenstein. 2009. Effects of yeast culture on peripartum intake and milk production of primiparous and multiparous Holstein cows. Prof. Anim. Sci. 25:487-495.

Robinson, P. H., and J. E. Garrett. 1999. Effect of yeast culture (Saccharomyces cerevisiae) on adaptation of cows to postpartum diets and on lactational performance. J. Anim. Sci. 77:988-999. https:/ doi.org/10.2527/1999.774988x.

Soder, K. J., and L. A. Holden. 1999. Dry matter intake and milk yield and composition of cows fed yeast prepartum and postpartum. J. Dairy Sci. 82:605-610. https://doi.org/10.3168/jds.S0022 -0302(99)75273-2.

Spring, P., C. Wenk, K. A. Dawson, and K. E. Newman. 2000. The effects of dietary mannaoligosaccharides on cecal parameters and the concentrations of enteric bacteria in the ceca of salmonellachallenged broiler chicks. Poult. Sci. 79:205-211. https://doi.org/ $10.1093 / \mathrm{ps} / 79.2 .205$

Stewart, C. S., H. J. Flint, and M. P. Bryant. 1997. The rumen bacteria. Pages 10-72 in The Rumen Microbial Ecosystem. P. N. Hobson and C. S. Stewart, ed. Chapman and Hall, London, UK.

Yuan, K., T. Liang, M. B. Muckey, L. G. Mendonca, L. E. Hulbert, C. C. Elrod, and B. J. Bradford. 2015a. Yeast product supplementation modulated feeding behavior and metabolism in transition dairy cows. J. Dairy Sci. 98:532-540. https://doi.org/10.3168/jds .2014-8468.

Yuan, K., L. G. Mendonca, L. E. Hulbert, L. K. Mamedova, M. B. Muckey, Y. Shen, C. C. Elrod, and B. J. Bradford. 2015b. Yeast product supplementation modulated humoral and mucosal immunity and uterine inflammatory signals in transition dairy cows. J. Dairy Sci. 98:3236-3246. https://doi.org/10.3168/jds.2014-8469.

\section{ORCIDS}

J. H. Harrison (ㄴ) https://orcid.org/0000-0003-0276-6985

A. Adams-Progar (ㄴ) https://orcid.org/0000-0002-6575-2807

E. Block ๑ https://orcid.org/0000-0003-2588-3236 